\title{
Serine/Arginine-Rich Splicing Factor 3
}

National Cancer Institute

\section{Source}

National Cancer Institute. Serine/Arginine-Rich Splicing Factor 3. NCI Thesaurus. Code C97787.

Serine/arginine-rich splicing factor $3(164 \mathrm{aa}, \sim 19 \mathrm{kDa})$ is encoded by the human SRSF3 gene. This protein plays a role in mRNA processing. 